\title{
INTENZIVNI PROGRAM NA OBMEJNEM OBMOČJU AVSTRIJE IN ČEŠKE
}

Osmo srečanje študentov geografije in njihovih profesorjev z univerz, ki sodelujejo v intenzivnem programu Socrates Erasmus (koordinacijo tega programa bo v prihodnje prevzel naš oddelek), je tokrat od 16. do 27. 9. 2006 preučevalo pojem in pomen meje na območju Spodnje Avstrije (Waldviertel in Weinviertel), južne Češke in Moravske (Jihočeský in Jihomoravský kraj). Območji sta bili do razpada Avstroogrske monarhije del skupne države. Šele nastanek Češke Republike kot samostojne države (1919) je na zemljevidu zarezal sedanjo državno mejo. Državi sta se različno razvijali zadnjih 85 let; predvsem v času hladne vojne so postale še bolj očitne razlike v gospodarskih sistemih, kmetijski in industrijski strukturi. Po letu 1945 so se zaprli mejni prehodi, železna zavesa je zaznamovala vsakdan in dolga desetletja do padca komunizma na Češkem leta 1990. S pristopom Češke v Evropsko Zvezo je to mejno območje postalo notranje evropsko mejno območje (in zato del programa INTERREG).

Tokratno srečanje bi lahko z več vidikov označili kot »naj«:

- $\quad$ sodelovalo je doslej največ univerz (Aberdeen, Lisboa, Sevilla, Innsbruck, Ljubljana, Cluj, Vilnius),

- povezovalo je največje študentov in profesorjev (45),

- največkrat smo fizično prečkali mejo med Avstrijo in Češko (tudi šestkrat dnevno!),

- $\quad$ z vidika logistike je bil to za organizatorja (dr. Klaus Franz, Univerza v Innsbrucku) največji podvig, saj je bilo potrebno na terenu koordinirati 6 kombijev.

Naš glavni namen je bil preučiti učinke meja v pokrajini in njihovo trdoživost (zlasti) pri ljudeh, ki na tem območju živijo in delajo. Meje ne obstajajo le na zemljevidih, v pokrajini, med narodi (velik del mejnega pasu pripada Sudetom) in jeziki, ampak so sestavni del vsakdana in miselnega sistema ljudi. Polpretekla politična zgodovina je ravno na tem območju Srednje Evrope zarisovala etnične in ustvarjala nove politične meje, ki so čez noč prekinile stoletne vezi: nekdanji prijatelji so postali tujci in »sovražniki«. Tovrstne meje so še danes precej globoko ukoreninjene pri tamkajšnjem (starejšem) prebivalstvu, nekateri stereotipi pa se tudi na širšem preučevanem območju zdijo »nepremagljivi«.

Kljub številnim razlikam pa imata obmejni območji na avstrijski in češki strani nekatere skupne značilnosti.

1. Za obe državi je to območje periferno. Na avstrijskem delu se je večina ljudi odselila na Dunaj ali v Linz. Okrožja Český Krumlov, České Budějovice in Jindřichův Hradec so po 2. svetovni vojni postala »še bolj periferna«, ker so se s hladno vojno znašla v neposredni bližini skoraj neprehodnega sistema železne zavese. Z odprtjem meje so se odselitveni procesi nekoliko upočasnili, na češki strani celo beležijo prebivalstveno rast.

2. Obstoječi cestni in železniški sistem dokaj dobro povezujeta obmejni območji z notranjostjo posameznih držav (na avstrijski strani je dobra cestna in železniška povezava do Dunaja in Linza), večinoma pa manjkajo ceste, ki bi prečkale mejo, maloštevilni in medsebojno oddaljeni mejni prehodi otežujejo dnevno komunikacijo. Kljub temu je cestni 
promet po letu 1990 močno porasel in na obstoječi sistem deluje pretirano obremenilno. Še vedno ni avtoceste med Linzem in Prago ali Dunajem in Prago. Ni razvit sistem javnega prevoza.

3. V državnem smislu dosegata regiji dobro polovico BDP. Znotraj obmejnega območja so tako v Avstriji kot na Češkem očitne velike regionalne razlike.

4. Kmetijstvo igra pomembno vlogo ohranjevalca kulturne pokrajine, čeprav zaposluje majhen delež delovno aktivnega prebivalstva:

- v avstrijskem delu le $1-4 \%$,

- $6 \%$ v Českih Budějovicah in $12 \%$ v Jindřichủvem Hradcu.

5. Na obeh straneh meje je območje redko poseljeno:

- gostota poselitve na avstrijskem delu je od 33 do $64 \mathrm{preb} . / \mathrm{km}^{2}$,

- Jihočeský kraj (največje upravne enote, 14 po vsej državi), katerega središče so České Budějovice (95.000 preb.) je najredkeje poseljen del Češke (63 preb./km²; kar je slaba polovica državnega povprečja). Podeželski del, ki je zaobjet v okrožjih Český Krumlov, České Budějovice in Jindřichủv Hradec, je še redkeje poseljen (37 - 48 preb./ $\mathrm{km}^{2}$ ). Jihomoravský kraj (prestolnica Brno ima 367.000 preb.) je gosteje poseljen kot Jihočeský kraj, nekoliko manj periferen in bolje gospodarsko razvit. Preučevali smo okrožje Znojmo, kjer imajo sedež velika kmetijska podjetja.

6. Gospodarski razvoj je zaznamovala nekoliko zakasnela industrijska revolucija, poseben pečat pa mu je dala železna zavesa. Na obeh straneh meje na podeželju ni velikih industrijskih obratov, le-ti so večinoma $\mathrm{v}$ redkih in majhnih mestih, kjer so ljudje zaposleni v industriji in terciarju. V Spodnji Avstriji sta tradicionalni tekstilna in lesna industrija (podobno tudi na Češkem), pa tudi gradbeništvo, ki je v zadnjih letih ustvarilo nekaj novih delovnih mest.

7. Večinoma je za obe območji značilnem podrazvit storitveni sektor:

- $\quad$ čeprav je $\mathrm{v}$ avstrijskem delu $\mathrm{v}$ zadnjem obdobju nekoliko pridobil na pomenu, a je pretežno skoncentriran v mestih (turizem, trgovina, zdravstvo),

- na češki strani je očiten manko glede razširjenosti, razvitosti in razvejanosti storitvenega sistema.

8. Na obeh delih obmejnega območja se je že v 14. stoletju pričelo specifično gojenje krapov, ki se je v precejšnjem obsegu ohranilo do danes:

- V Avstriji imajo 2.700 ha ribnikov (večinoma na območju Spodnje Avstrije), kjer prevladujejo manjša družinska podjetja $\mathrm{z}$ dolgoletno tradicijo, danes usmerjena predvsem v ekološko proizvodnjo s priznano blagovno znamko (Waldviertler Karpf) in osredotočena predvsem na lokalni in regionalni trg,

- na Češkem imajo 45.000 ha ribnikov (večinoma na preučevanem območju), pretežno v lasti velikih državnih (zdaj tudi že mednarodnih) podjetij, ki z masovno proizvodnjo in nižjo ceno prodirajo na evropski trg, njihova blagovna znamka se šele uvaja.

Seveda bi lahko vsem naštetim podobnostim v pokrajini našli tudi izjeme, a splošni trendi ostajajo. Očitne so tudi razlike, verjetno najbolj pokrajinsko razvidne v agrarni strukturi. $\mathrm{Za}$ avstrijski del so značilne družinske kmetije, katerih lastniki so polkmetje (2/3 vseh), ki 
jim majhna posest in precej neugodne naravne razmere za kmetovanje ne omogočajo konkurenčnosti na trgu. Na Češkem se soočajo s preobrazbo, razpadom in iskanjem novih razvojnih poti za nekdanja velika državna kmetijska posestva.

Študenti so bili razdeljeni v skupine, ki so preučevale:

- razširjenost in pomen ekološkega kmetijstva na obeh straneh meje (mnogo bolj razvito v avstrijskem delu),

- pomen akvakulture (predvsem gojenja krapov) v preteklosti, danes in prihodnje razvojne možnosti,

- učinke meje v pokrajini (zemljiško-posestna razdelitev, oblikovanje cestne infrastrukture, izgradnja varovalnega sistema ipd.),

- gospodarske učinke politične razmejitve na primeru Gmünda in Českych Velenic (mesto Gmünd je doživelo podobno usodo kot Gorica),

- socialno-kulturne ostanke meje,

- meje v glavah lokalnega prebivalstva (preučevanje izvedeno $\mathrm{z}$ anketiranjem).

Skupine so po enotedenskem skupnem spoznavanju območja izvajale podrobnejše raziskave na terenu v drugem delu našega druženja in zadnji dan predstavile tudi zanimive, izvirne in včasih tudi nekoliko provokativne ugotovitve. Njihovo delovanje je zabeležil tudi regionalni časopis, rezultate bodo predstavili tudi na spletnih straneh, $\mathrm{v}$ študentskih in strokovnih medijih.

Skupne ugotovitve so potrdile hipotezo, da je potrebnih nekaj generacij, da se spremenijo gledanja, posledično pa tudi ravnanja ljudi, kijihje meja fizično ločila. Veliko zavoro pri krepitvi raznovrstnih stikov pri večini prebivalcev predstavlja jezikovna ovira. Zato je potrebno zelo pozitivno oceniti izvajanje dvojezičnega pouka na nekaterih šolah $v$ obmejnem pasu, turistične čezmejne pobude, skupna druženja in zlasti ustanovitev prvega čezmejnega industrijskega parka v Gmündu. Ljudje so se veselili odprtja, a se bojijo negativnih gospodarskih učinkov.

Irma Potočnik Slavič 